Culture and Ideology under the Seleukids 



\section{Culture and}

\section{Ideology under the Seleukids}

Unframing a Dynasty

Edited by

Eva Anagnostou-Laoutides and Stefan Pfeiffer

\section{DE GRUYTER}


ISBN 978-3-11-075557-2

e-ISBN (PDF) 978-3-11-075562-6

e-ISBN (EPUB) 978-3-11-075568-8

Library of Congress Control Number: 2021945784

Bibliographic information published by the Deutsche Nationalbibliothek

The Deutsche Nationalbibliothek lists this publication in the Deutsche Nationalbibliografie; detailed bibliographic data are available on the Internet at http://dnb.dnb.de.

(C) 2022 Walter de Gruyter GmbH, Berlin/Boston

Printing and binding: $\mathrm{CPI}$ books $\mathrm{GmbH}$, Leck

www.degruyter.com 